Jurnal Pendidikan IPA Indonesia

\title{
SCIENCE PROCESS SKILLS ANALYSIS OF SCIENCE TEACHER ON PROFESSIONAL TEACHER PROGRAM IN INDONESIA
}

\author{
A. M. Setiawan ${ }^{* 1}$ and Sugiyanto ${ }^{2}$ \\ ${ }^{1,2}$ Science Education Study Program, FMIPA Universitas Negeri Malang, Malang, Indonesia \\ DOI: $10.15294 /$ jpii.v9i2.23817
}

Accepted: March 20 ${ }^{\text {th }} 2020$. Approved: June 25 ${ }^{\text {th }} 2020$. Published: June $30^{\text {th }} 2020$

\begin{abstract}
The low level of science teacher graduation in the professional teacher program in the last two years has become a severe concern for researchers in higher education. Here we analyze these problems by measuring the Science Process (SP) Skills of science teachers in Indonesia through this program. Data collection procedures are interviews, worksheets, and questionnaires, while data analysis techniques use mixed methods, consist of quantitative and qualitative methods simultaneously. The SP skills data obtained were Observing $76.1 \%$, Proposing Hypothesis 76.4\%, Planning an Experiment 60.0\%, Utilizing Tools 57.2\%, Interpreting 39.4\%, Applying Concept 48.1\%, and Communicating $18.3 \%$. The lowest percentage is in interpreting skills and communicating skills. Based on the analysis result, the causes are the short time teaching experience and the educational background of science teachers who are not linear with their competence.
\end{abstract}

(C) 2020 Science Education Study Program FMIPA UNNES Semarang

Keywords: science process skill; professional teacher program; science teacher

\section{INTRODUCTION}

Professional Teacher Program is a policy of the Ministry of Education and Culture to realize the objectives of national education where the golden generation towards superior Indonesian society the future is achieved. In its implementation, this program is carried out in various education-based universities in Indonesia, one of them is Universitas Negeri Malang. Based on the interviews with the Helpdesk of Professional Teacher Program, it was found that the passing grade of science teachers participating in these programs in the years 2018 was $49,0 \%$, while in the years 2019 was $61,7 \%$. Both of these percentages are still very low because the expected graduation rate of this program is $70 \%$. The urgency in this study is very crucial because the graduation target set in 2020 is $100 \%$. Besides, the Professio-

*Correspondence Address

E-mail: agung.mulyo.fmipa@um.ac.id nal Teacher Program competency examination in 2020 by the Ministry of Education and Culture will be held in November, so that the time needed to solve this problem is only \pm six months since independent learning begins.

These problems raise questions among university academics, such as their science concepts understanding's profiles of science teachers, their science literacies profiles of science teachers, and their science process (SP) skills profiles of science teachers in Indonesia. Here, we interested in answer one of these questions, such as how the SP skills of science teachers in Indonesia. SP skills is a crucial ability possessed by science teachers so that their students have an excellent scientific attitude as the true Nature of Science (NoS) (Patonah et al., 2018). Therefore, to improve their competence as teachers, science teachers must improve their SP skills so that the learning process more effective and more quality to students. 
The results of a complete study related to SP skills from several international scientific journals will be explained as follows. SP skills have several indicators integrated inquiry-based learning, such as defining a problem, formulating hypotheses, observing, interpreting results, using scientific terms, drawing scientific figures, and making scientific explanation (Mutlu, 2020). Activities in SP skills if carried out consistently in the learning process, can increase student perceptions in "careers in science" and "careers with science" (Salonen et al., 2017). SP skills can be realized in the classroom through learning-science-by-doing-science (LSDS) activities, where this activity will encourage the authentic science research experience that drives students to think like scientists and to act like scientists (Labouta et al., 2018). SP skills can also be utilized to improve students understanding perceptions about their quantitative skills (Matthews et al., 2015; Rylands et al., 2013). Besides quantitative skills, an essential factor in SP skills is communication skills because excellent communication skills can be used as teaching resources for graduate science education and undergraduate science education and curriculum improvement (Mercer-Mapstone \& Kuchel, 2017; Hill et al., 2019). While the instruments used to measure SP skills can be reviewed from 3 subskills levels such as science specification, scientific thinking, and science metacognition (Kruit et al., 2018). The students' SP skills increased more significantly using scientificbased learning methods than using conventional learning process (Prabowo, 2015). Need to know that the learning process with SP skills not only improve students' knowledge, discover facts, concepts, and values independently, but also develop their understanding (Siahaan et al., 2017).Because SP Skills helps students learning by doing science, experiencing the science process, linking science objects with their daily life, and facilitating students to communicate their scientific and technological findings in real life (Munatzir et al., 2019).

The result of the preliminary study about teacher's SP skills is obtained as follows. Teacher's SP skills can be improved through a professional development program on science teaching and learning for one year, by providing training on the implementation of the science curriculum, inquiry-based instruction, management of the classroom, and technologies in the classroom (Dailey \& Robinson, 2017; Sarkar et al., 2020). The aspect of Communication skills of SP skills can help teachers and scientists to deliver their research idea with middle school students (Yonai $\&$ Blonder, 2020).In South Africa, the perception of science teachers about the implementation and development of SP skills is still deficient due to their lack of confidence as science teachers and understanding of SP skills in the past and the present (Ambros et al., 2014). Further research on SP skills of science teachers in the teacher education program produced two things: SP skills can be obtained from the development of the understanding of science concepts, and SP skills can be obtained from the teaching experience of science teachers themselves (Molefe \& Stears, 2014). In Australia, a professional learning program for science teachers is also conducted to improve the quality of the science teaching in 3 frameworks related to teacher's SP skills, such as content, pedagogy, and student skill outcomes (Loughland \& Nguyen, 2016). Science teachers can develop SP skills assessment to improve their student's skills in middle school or junior high school with following the rules of the National Science Education Standard (NSES) and K-12 Framework Science Educations (FSE) (Lou et al., 2015). Besides, by looking at students' perceptions about their science skills like scientific knowledge, oral communication, scientific writing, quantitative skills, team works, and ethical thinking, science teachers can improve the development of their SP skills through teaching activities and task assessment (Hodgson et al., 2014).

However, the SP skills of science teachers in professional teachers program still not finished yet. Even though we hope the students have excellent SP skills, the teachers must have good SP skills too (Anwar et al., 2012). The novelty in this study is based on the SP skills profiles information of science teachers in Indonesia. While the limitation of these research objectives is the SP skills of science teachers in the professional teacher's program in Indonesia because the passing grade of science teachers participating in these programs is still very low. Therefore, this study aims to analyze the SP skills profiles of science teachers in the professional teacher's program organized by the Ministry of Education and Culture of the Republic of Indonesia.

\section{METHODS}

In this research, the authors used a descriptive research method with a qualitative approach. The research procedure consisted of 4 stages, like interviews, literature review, worksheets, and questionnaires, as shown in table 1 . In the data collection process, we use research instruments such as SP skills worksheets, and questionnaires sheets. 
The SP skills worksheet consists of 7 questions derived from SP skills indicators adapted from several references that consist of observing, proposing a hypothesis, planning an experiment, utilizing tools, interpreting, applying the concept, and communicating (Widanti \& Aloysius, 2020; Munatzir et al., 2019; Patonah et al., 2018; Siahaan et al., 2017). The questionnaire sheet consisted of 20 questions that discussed teaching experiences and educational background. For teaching experience consists of 7 questions that review in what year the participant first time became a teacher and subjects taught, in what year participants taught science, how long to teach science, learning methods are often used, and the reasons for using these methods. Whereas for the educational background consists of 13 questions that discuss the level of participant education $(\mathrm{D} 3 / \mathrm{S} 1 / \mathrm{S} 2)$, the name of the university or institution, the majors and study programs took, and the accreditation of study programs when they graduate. All of the research instruments are then validated to the lecturers of the professional teacher program in the science education study program at Universitas Negeri Malang. The validation result of all research instruments is $91 \%$ for the SP skills worksheet, and $97 \%$ for the questionnaire sheet with valid criteria.

Table 1.Research Procedure of SP Skills Analysis

\begin{tabular}{|c|c|c|c|}
\hline No & $\begin{array}{c}\text { Research } \\
\text { Tools }\end{array}$ & $\begin{array}{c}\text { Research } \\
\text { Subject }\end{array}$ & $\begin{array}{c}\text { Data Collec- } \\
\text { tion }\end{array}$ \\
\hline 1 & Interviews & $\begin{array}{c}\text { Helpdesk of } \\
\text { Professional } \\
\text { Teacher } \\
\text { Program }\end{array}$ & $\begin{array}{l}\text { The passing } \\
\text { grade data } \\
\text { in 2018-2019 } \\
\text { and its par- } \\
\text { ticipants. }\end{array}$ \\
\hline 2 & $\begin{array}{c}\text { Literature } \\
\text { review }\end{array}$ & $\begin{array}{l}\text { Internation- } \\
\text { alJournals\& } \\
\text { proceedings }\end{array}$ & $\begin{array}{l}\text { Bibliography } \\
\text { of SP skills } \\
\text { and its indica- } \\
\text { tors. }\end{array}$ \\
\hline 3 & Worksheet & $\begin{array}{l}\text { Science } \\
\text { Teachers }\end{array}$ & $\begin{array}{l}\text { SP skills pro- } \\
\text { files data. }\end{array}$ \\
\hline 4 & $\begin{array}{l}\text { Question- } \\
\text { naires }\end{array}$ & $\begin{array}{l}\text { Science } \\
\text { Teachers }\end{array}$ & $\begin{array}{c}\text { Teaching } \\
\text { experience; } \\
\text { Educational } \\
\text { background. }\end{array}$ \\
\hline
\end{tabular}

Data analysis techniques used are mixed methods (Creswell \& Creswell, 2017). The quantitative method for calculating the percentage of SP skills profiles, teaching experience, and educational background. The qualitative method to describe the calculation results obtained, as in table 2 (Widanti \& Aloysius, 2020; Munatzir et al., 2019; Patonah et al., 2018; Siahaan et al., 2017). Based on these criteria, we can identify the level of each SP skill indicator possessed by science teachers in the professional teacher program (Widoyoko, 2009).

Table 2. Percentage of Achievement Criteria

\begin{tabular}{cc}
\hline Achievement Criteria & Percentage \\
\hline Very Good & $81 \%-100 \%$ \\
Good & $61 \%-80 \%$ \\
Moderate & $41 \%-60 \%$ \\
Poor & $21 \%-40 \%$ \\
Very Poor & $0 \%-20 \%$ \\
\hline
\end{tabular}

The location of the research is located in the professional teacher's program building in the Universitas Negeri Malang, with a total sample is 120 science teachers from various regions in Indonesia such as Sumatera, Kalimantan, Jawa, Sulawesi, and Papua.

\section{RESULTS AND DISCUSSION}

The results of the science teacher's SP skills in the professional teacher's program are shown in table 3 below. For observing skills and proposing hypothesis skills, a percentage of $76,1 \%$ and $76,4 \%$ were obtained with good criteria. For planning experiment skills and utilizing skills, a percentage of $60,0 \%$ and $57,2 \%$ were obtained with moderate criteria. For interpreting skills, applying concept skills, and communicating skills, the percentage sequentially amounted to $39,4 \% ; 48,1 \%$; and $18,3 \%$ with poor criteria, moderate criteria, and very poor criteria.

Table 3. Profiles of SP Skills of Professional Teacher Program

\begin{tabular}{cccc}
\hline No & $\begin{array}{c}\text { Science Process } \\
\text { Skills }\end{array}$ & Percentage & Criteria \\
\hline 1 & Observing & $76,1 \%$ & Good \\
2 & $\begin{array}{c}\text { Proposing hy- } \\
\text { pothesis }\end{array}$ & $76,4 \%$ & Good \\
& $\begin{array}{c}\text { Planning an } \\
\text { experiment }\end{array}$ & $60,0 \%$ & Moderate \\
4 & Utilizing tools & $57,2 \%$ & Moderate \\
5 & Interpreting & $39,4 \%$ & Poor \\
6 & Applying con- & $48,1 \%$ & Moderate \\
& cept & & Very \\
7 & Communicating & $18,3 \%$ & Poor \\
\hline
\end{tabular}


From the data it appears that the value of SP skills of science teachers in the professional teacher's program is moderate in 3 aspects, like planning experiment skills, utilizing tools skills, and applying concept skills whereas the SP skills are high in 2 aspects, like observing skills and proposing hypothesis skills. However, the value of SP skills is low and very low in interpreting skills and communicating skills. The causes of this results can be traced based on two things, consist of a) the length of teaching experience (Mahanani et al., 2020; Antony et al., 2019); and b) educational background (Agfar et al., 2018; Rahmani, 2018)science teacher in the professional teacher's program.

The percentage results of the teaching experience of science teachers are shown in table 4. Table 4 shows that the most dominant duration of teaching experience is 7 to 9 years, with a percentage of $33 \%$. Whereas for 15 to 17 years, the percentage is $0 \%$. It means that from the subject sample, no science teacher taught for 15 to 17 years. It is because the sample of participants who participated in the professional teacher program at Universitas Negeri Malang in this range did not exist. What concerns us here is the percentage of teaching experience of science teachers for more than 17 years. The low percentage of teaching experience of science teachers for more than 17 years has caused the low SP skills profile results. Because teachers who have more extensive teaching experience, have better teaching skills, and vice versa (Antony et al., 2019). Besides, teachers with more extensive teaching experience have better pedagogical and content knowledge than teachers with less teaching experience (Antony et al., 2019). It is supported by the results of other researchers who found that teaching experience affects teacher knowledge and teacher self-efficacy in their teaching material( and teaching experience influences work motivation on laboratory management in conducting experiments (Mahanani et al., 2020).

Table 4. Percentage of the Teaching Experience of Science Teacher

\begin{tabular}{cc}
\hline Teaching Experience & Percentage (\%) \\
\hline$\leq 1$ year & 6 \\
$1<$ years $\leq 3$ & 11 \\
$3<$ years $\leq 5$ & 6 \\
$5<$ years $\leq 7$ & 11 \\
$7<$ years $\leq 9$ & 33 \\
$9<$ years $\leq 11$ & 11 \\
$11<$ years $\leq 13$ & 6 \\
$13<$ years $\leq 15$ & 11 \\
$15<$ years $\leq 17$ & 0 \\
$>17$ years & 6 \\
\hline
\end{tabular}

Also, other contributing factors related to teaching experience based on the results of the questionnaire are not all teachers who have more extensive teaching experience in schools teaching science subjects. Some of them, when the first time they became a teacher, did not teach science but taught other subjects in junior high school. Besides, learning methods that are often used as well as the reasons for using these methods are also the causes of the low SP of science teacher's skills (Van et al., 2020). It is caused by the many natural science teachers who are still applying conventional learning, where the learning process is centred on the teacher, not on students (Madyani et al., 2019). The lack of practical activities, science demonstrations, and group discussions during the science learning process is caused by the lack of creative ideas from science teachers in making a science practicum from the material they teach (Dewantara et al., 2019; Rodiah et al., 2020; Madyani et al., 2019; Sidek et al., 2020). Even in some regions such as Papua, Kalimantan, and Sumatera, there are still many schools where natural science teachers have limited teaching tools (Nau\& Djalo, 2019). It made their SP skill very low.

Furthermore, the results of the science teacher educational background in the professional teacher program are shown in Figure 1. From this figure, we can make a sequence of the educational background percentage of science teachers from the smallest to the largest as follows. Educational background percentage for S1 chemistry education is 5\%; for S2 physics and S2 science education is $6 \%$; for $\mathrm{S} 1$ physics education is $11 \%$; for S1 physics is $17 \%$; for S1 biology is $22 \%$, and for S1 Biology Education is 33\%.

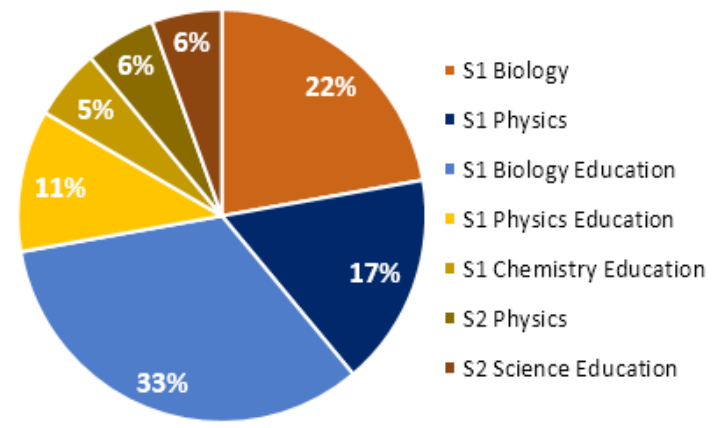

Figure1. The Diagram of Science Teacher Educational Background in the Professional Teacher Program

The results of the data in Figure 1 provide information that the smallest educational background of science teachers is S1 chemistry education and the largest is S1 biology education. While the percentage of educational background that 
linear for science teachers themselves, S2 science education, just only $6 \%$. The picture also shows that there are no science teachers who come from S1 science education because the existence of an S1 science education study program that is still entirely new (since 2013-2014).In addition to the level of education possessed by science teachers, the low SP skills can also be caused by the type of university or institution and the accreditation of study programs when they graduate (Hasanah \& Shimizu, 2020). Some of the science teachers are alumni of study programs whose accreditation is still not proper and come from private universities in small areas that are still new and not accredited and causes the education provision experienced by science teachers during lectures that are not good and still lack experience (Sidek et al., 2020). So that the new science teachers produced are challenging to develop because of their lack of understanding of science concepts (Van et al., 2020; Hasanah \& Shimizu, 2020; Sidek et al., 2020).

The category of SP skills profiles on aspects interpreting skills and communication skills, with poor criteria and very poor criteria, are caused by the many educational backgrounds of science teachers who are not linear with their competence. Although they are in the same group of sciences, is mathematics and natural sciences, the linearity of the educational background still influences teacher competence significantly. It is supported by the results of previous studies where educational background significantly influences attitudes, someone's skill in identifying a problem, and analyze the problem (Agfar et al., 2018). There is a significant influence of the educational background in choosing teaching methods and techniques, expressing ideas and experiences, understanding issue, implementing and delivering solution (Rahmani, 2018).

\section{CONCLUSION}

The low SP skills profiles of science teachers in the professional teacher program found in the aspects of interpreting skills and communication skills. Its caused by the short years of teaching experience of science teachers and the educational backgrounds of science teachers that are not linear with their competence. The educational implications of this research for science education that is science teaching in junior high schools in the future must be taught by a teacher who is purely from the educational background of science education study programs. Because if the science teacher's educational background comes only from one particular department, for example, biology, physics, or chemistry, then the strengthening of science learning is carried out only in one of these fields. As a result, student SP skills are low due to low SP science teacher skills in other fields of science. As a suggestion in the future research to get more comprehensive information about the profiles of science teachers in the professional teacher's program, the research topic needs to be focused on mastering science concepts and their scientific literacy.

\section{REFERENCES}

Agfar, A., Munandar, A., \& Surakusumah, W. (2018, May). Environmental literacy based on educational background. In Journal of Physics: Conference Series (Vol. 1013, No. 1, p. 012008). IOP Publishing.

Ambross, J., Meiring, L., \& Blignaut, S. (2014). The implementation and development of science process skills in the natural sciences: A case study of teachers' perceptions. Africa Education Review, 11(3), 459-474.

Antony, M. K., Subali, B., Pradana, S. P., Hapsari, N., \& Astuti, F. E. C. (2019, December). Teacher's TPACK Profile: The Affect of Teacher Qualification and Teaching Experience. In Journal of Physics: Conference Series (Vol. 1397, No. 1, p. 012054). IOP Publishing.

Anwar, Y., Rustaman, N. Y., \& Widodo, A. (2012). Kemampuan subject specific pedagogy calon guru biologi peserta program pendidikan profesional guru (ppg) yang berlatar belakang basic sains pra dan post workshop. Jurnal Pendidikan IPA Indonesia, 1(2).

Creswell, J. W., \& Creswell, J. D. (2017). Research design: Qualitative, quantitative, and mixed methods approaches. Sage publications.

Dailey, D., \& Robinson, A. (2017). Improving and sustaining elementary teachers' science teaching perceptions and process skills: A postintervention study. Journal of Science Teacher Education, 28(2), 169-185.

Dewantara, D., Mahtari, S., Misbah, M., \& Haryandi, S. (2019). Student Responses in Biology Physics Courses Use Worksheets Based on Scientific Literacy. Prisma Sains: Jurnal Pengkajian Ilmu dan Pembelajaran Matematika dan IPA IKIP Mataram, 7(2), 192-197.

Hasanah, U., \& Shimizu, K. (2020). Crucial Cognitive Skills in Science Education: A Systematic Review. Jurnal Penelitian dan Pembelajaran IPA, 6(1), 36-72.

Hill, M. A., Overton, T. L., \& Thompson, C. D. (2019). Evaluating the impact of reflecting on curriculum-embedded skill development: the experience of science undergraduates. Higher Education Research \& Development, 1-17. 
Hodgson, Y., Varsavsky, C., \& Matthews, K. E. (2014). Assessment and teaching of science skills: whole of programme perceptions of graduating students. Assessment \& Evaluation in Higher Education, 39(5), 515-530.

Kruit, P. M., Oostdam, R. J., van den Berg, E., \& Schuitema, J. A. (2018). Assessing students' ability in performing scientific inquiry: instruments for measuring science skills in primary education. Research in Science \& Technological Education, 36(4), 413-439.

Labouta, H. I., Kenny, N. A., Li, R., Anikovskiy, M., Reid, L., \& Cramb, D. T. (2018). Learning science by doing science: an authentic science process-learning model in postsecondary education. International Journal of Science Education, 40(12), 1476-1492.

Lou, Y., Blanchard, P., \& Kennedy, E. (2015). Development and validation of a science inquiry skills assessment. Journal of Geoscience Education, 63(1), 73-85.

Loughland, T., \& Nguyen, H. T. M. (2016). Using the instructional core to implement a professional learning programme for primary science teachers in Australia: teacher learning and student skill outcomes. Teacher Development, 20(4), 498520.

Madyani, I., Yamtinah, S., \& Utomo, S. B. (2019). Profile of Creative Thinking Skills on Junior High School Students in Science Learning by Gender. Scientiae Educatia: Jurnal Pendidikan Sains, 8(2), 119-130.

Mahanani, C., Wening, S., Susanto, M. R., \& Sudirman, A. (2020, January). The effect of laboratory knowledge, teaching practice experience, and work motivation on laboratory management. In Journal of Physics: Conference Series (Vol. 1446, No. 1, p. 012042). IOP Publishing.

Mercer-Mapstone, L., \& Kuchel, L. (2017). Core skills for effective science communication: A teaching resource for undergraduate science education. International Journal of Science Education, Part B, 7(2), 181-201

Matthews, K. E., Adams, P., \& Goos, M. (2015). The influence of undergraduate science curriculum reform on students' perceptions of their quantitative skills. International Journal of Science Education, 37(16), 2619-2636.

Molefe, L., \& Stears, M. (2014). Rhetoric and reality: Science teacher educators' views and practice regarding science process skills. African Journal of Research in Mathematics, Science and Technology Education, 18(3), 219-230.

Munatzir, V., Rusli, M. A., \& Mun'im, A. (2019, October). Development and validation of integrated science students worksheet based on science process skills. In Journal of Physics: Confer- ence Series (Vol. 1317, No. 1, p. 012206). IOP Publishing.

Mutlu, A. (2020). Evaluation of students' scientific process skills through reflective worksheets in the inquiry-based learning environments. Reflective Practice, 21(2), 271-286.

Nau, G. W., \& Djalo, A. (2019). The Effect of Practical-Based Jigsaw Strategy on Science Process Skills of Students. Scientiae Educatia: Jurnal Pendidikan Sains, 8(2), 196-206.

Patonah, S., Nuvitalia, D., \& Saptaningrum, E. (2018, March). Content analysis of science material in junior school-based inquiry and science process skills. In Journal of Physics: Conference Series (Vol. 983, No. 1, p. 012167). IOP Publishing.

Prabowo, S. A. (2015). The effectiveness of scientific based learning towards science process skill mastery of PGSD students. Jurnal Pendidikan IPA Indonesia, 4(1), 15-19.

Rahmani, B. D. (2018, January). Differential item functional analysis on pedagogic and content knowledge (PCK) questionnaire for Indonesian teachers using RASCH model. In Journal of Physics: Conference Series (Vol. 948, No. 1, p. 012061). IOP Publishing.

Rodiah, S., Komala, R., \& Rusdi, R. (2020). The Correlation Between Biology Learning Outcomes and Senior High School Students' Self Concept. Jurnal Penelitian dan Pembelajaran IPA, 6(1), 141-151.

Rylands, L., Simbag, V., Matthews, K. E., Coady, C., \& Belward, S. (2013). Scientists and mathematicians collaborating to build quantitative skills in undergraduate science. International Journal of Mathematical Education in Science and Technology, 44(6), 834-845.

Salonen, A., Hartikainen-Ahia, A., Hense, J., Scheersoi, A., \& Keinonen, T. (2017). Secondary school students' perceptions of working life skills in science-related careers. International Journal of Science Education, 39(10), 1339-1352.

Sarkar, M., Overton, T., Thompson, C. D., \& Rayner, G. (2020). Academics' perspectives of the teaching and development of generic employability skills in science curricula. Higher Education Research \& Development, 39(2), 346-361.

Siahaan, P., Suryani, A., Kaniawati, I., Suhendi, E., \& Samsudin, A. (2017, February). Improving students' science process skills through simple computer simulations on linear motion conceptions. In Journal of Physics: Conference Series (Vol. 812, No. 1, p. 012017). IOP Publishing.

Sidek, R., Halim, L., Buang, N. A., \& Arsad, N. M. (2020). Fostering Scientific Creativity in Teaching and Learning Science in Schools: A Systematic Review. Jurnal Penelitian dan Pembelajaran IPA, 6(1), 13-35. 
Van Hien, N., Hai, N. D., \& Van Bien, N. (2020). Exploring Vietnamese Students' Participation and Perceptions of Science Classroom Environment in STEM Education Context. Jurnal Penelitian dan Pembelajaran IPA, 6(1), 73-86.

Widanti, Y. B. R., \& Aloysius, S. (2020, January). Analysis of science process skills in student worksheet on microorganism topics for senior high school. In Journal of Physics: Conference Series (Vol. 1440, No. 1, p. 012069). IOP Publishing.
Widoyoko, E. P. (2009). Evaluasi program pembelajaran. Yogyakarta: pustaka pelajar, 238.

Yonai, E., \& Blonder, R. (2020). USE YOUR OWN WORDS! Developing science communication skills of NST experts in a guided discourse. International Journal of Science Education, Part $B, 10(1), 51-76$. 